\title{
Engineering Barriers: An Empirical Investigation into the Mechanics of Downward Mobility
}

\author{
Bonnie Slade York University ${ }^{1}$
}

\begin{abstract}
Résumé
Le présent article explore la réglementation de la profession d'ingénieur et la façon dont le processus-même d'obtention de la licence a des répercussions sur la situation des ingénieurs immigrants sur le marché du travail. L'article s’inspire de l'ontologie sociale et de la méthode d'enquête de l'ethnographie institutionnelle pour dresser une carte du processus d'obtention de licence en Ontario, où les ingénieurs immigrants sont traités comme des exceptions, bien qu'ils soient en fait plus nombreux que les diplômés d'écoles de génie ontariennes. Les ingénieurs immigrants, d'abord soumis à une évaluation individuelle de leurs études et de leur expérience de travail, doivent aussi avoir un an d'expérience de travail au Canada. La recherche montre qu'il leur est difficile d'obtenir une licence. L'article présente en détail les processus de travail administratif qui entraînent des retards et des difficultés pour les ingénieurs immigrés et explore les répercussions sur l'employabilité de l'absence d'une licence.
\end{abstract}

\begin{abstract}
This paper explores the regulation of professional engineering and how the licensing process itself impacts the labour market position of immigrant engineers. Guided by the social ontology and method of inquiry of institutional ethnography, this paper provides a map of the licensing process for engineering in Ontario and shows how immigrant engineers are constructed as exceptions to the process, despite the fact that immigrant engineers outnumber Ontario engineering graduates. Having to first go though individualized academic and work experience assessments, they also require one year Canadian work experience. Research has shown that it is difficult for immigrant engineers to successfully complete the licensing process. This paper details the administrative work processes that cause delays and difficulties for immigrant engineers, and discusses the labour market implications of not having a professional licence.
\end{abstract}

1 Bonnie Slade is a Post Doctoral Fellow at York University. Her research interests are in women's studies, migration, the social construction of knowledge, and the sociology of work. She is the author of "Highly Skilled and Under-theorized: Women Migrant Professionals" in R. Baaba Folson (Ed.) Calculated Kindness: Global Economic Restructuring and Canadian Immigration \& Settlement Policy (2004: pp. 102-116) and co-author of "Hell on my Face: The Production of Workplace Illiteracy" with Nancy S. Jackson in M.L. DeVault (Ed.). Life, Power, and Social Inclusion in The New Economy: People at Work (2008: 25-39). 


\section{Introduction}

Before she immigrated to Canada, Ivy Zheng, a mechanical engineer who worked in the China Academy of Launch Vehicle Technology, received a national award for her design of electric and hydraulic control components for the Chinese space program. In Canada, Ms. Zheng has not worked in engineering and has only been able to find part-time work in a Chinese restaurant and a fast food chain. During her 18-month engineering job search employers told her that she was not hired because of her lack of Canadian work experience. In her words:

I cannot persuade anyone to take me seriously in Canada ... There was only once, I reached a human resource person by chance [usually she was screened by the receptionist]. The only question he asked me was 'do you have Canadian experience?' I answered him honestly; I am new immigrant looking for my first job in Canada. But I had nine years of experience in mechanical engineering field in China. He said sorry. We need someone who has Canadian experience. I was confused. The Canadian government gives me the visa as an independent skilled immigrant that means the government approves my foreign credentials. But why no Canadian company approves my experience. If no companies would give me the first chance, how can I gain the Canadian experience (Zheng, 2005: 6)?

The inability to obtain relevant Canadian engineering work has serious consequences for Ms. Zheng's ability to both qualify for a professional engineering licence, and continue working in her profession in Ontario.

While the engineering license has been identified as a critical credential for immigrant engineers to gain relevant employment (Canadian Council of Professional Engineers, 2003: 50), the Council for Access to the Profession of Engineering has reported that less than five per cent of immigrant engineers successfully complete the licensing process (Bambrah, 2006b). Without a professional licence, immigrant engineers face great difficulty in gaining relevant employment, and often end up in precarious employment. Data from a survey of 1,016 immigrant engineers revealed that only 15 per cent were working in engineering while 57 per cent were unemployed, and 28 per cent were working in another field (Bambrah, 2006b). It is common for immigrant professionals like Ivy Zheng to experience downward mobility in Canada. Their transition from highly-sought-after professionals to precarious workers is structured through a nexus of power relations mediated by the state, professional regulatory bodies and employers. The deprofessionalization of immigrant professionals presents an analytic opportunity to examine how class, gender and race function as relational processes rather than as fixed traits, and how configurations shift with changes in place and time. In Toronto, Ivy Zheng encountered an entirely new set of gender, race and class relations; her identity 


\section{Engineering Barriers: An Empirical Investigation \\ into the Mechanics of Downward Mobility}

shifted from being a respected engineer who was part of the dominant culture to being a racialized immigrant woman in a male dominated profession.

Roxana Ng has argued that to understand how categories such as gender, race and class are produced, reproduced and accomplished as social facts they need to be empirically investigated in the actions of people (1996; 1995; 1993; 1981). This paper takes up Ng's call for empirical investigation and provides a textual analysis of the "Academic Requirements" section of the "Licensing Guide and Application for Licence" (PEO, 2007a; henceforth referred to as the Guide and the Application) administered by Professional Engineers Ontario (PEO), the professional regulatory body for engineering in Ontario. Guided by the ontology, epistemology and method of institutional ethnography (Smith, 2005), this paper analyzes the licensing process for engineers in Ontario, mapping the process for immigrant engineers (Ng, 1995; Smith, 1997). The conceptual framework of institutional ethnography provides the means to analyze how the downward class mobility of immigrant engineers is accomplished through ordinary work practices of PEO. The starting point of this analysis is a disjuncture experienced by immigrant engineers such as Ivy Zheng, or Nanthee Veluppilai whose story was profiled in an article from the Toronto Star:

A school board co-op program helped Nanthee Veluppilai, an experienced civil engineer, become a Markham building inspector. He's not using all his skills but feels he will succeed if he shows his ability. Still, he wonders why Canada "dumps" so many professional immigrants. You're an experienced professional who speaks good English. You have money in the bank, and you want to immigrate to Canada from, say, India or Sri Lanka, Hong Kong or Pakistan. The consular official's eyes light up. You're precisely the kind of newcomer the country wants. A brain gain, not a drain. The green light is given. Nobody has warned you that you're not going to be able to walk off the plane and straight into your profession. That if you're an engineer, say, the process of getting a licence may take years and you won't get it without somehow gaining Canadian work experience first. Nobody will have told you that the middle-class life you and your family are leaving won't necessarily be duplicated here. With savings depleted, it could easily turn into a scramble to put food on the table (Hurst, 1999: 1).

While immigrant engineers are recruited for their education and work experience, once they settle in Ontario and apply for a professional licence, they face a complex, lengthy textually mediated application process which is impossible to complete without gaining relevant Canadian work experience (Slade, 2008; 2003).

The type of textual analysis presented in this article follows in the tradition of Dorothy Smith in "Report and Repression: Textual Hazards for Feminists in the Academy" (1997) 
and Ng in "Multiculturalism as Ideological Practice: A Textual Analysis" (1995). While the experiences of Ivy Zheng and Nanthee Veluppilai provide an entry point into the extended set of social relations that organize the labour market access of thousands of immigrants, the texts are analyzed as a window into the licensing process that is carried out by various people at different times; when activated, the texts coordinate peoples' actions and give shape to the licensing process itself. The focus on texts is a critical element of an institutional ethnographic research study. According to Smith:

Texts are the primary medium (though not the substance) of power. The work of administration, of management, of government is a communicative work. Organizational and political processes are a form of action coordinated textually and getting done in words. It is an ideologically structured mode of action - images, vocabularies, concepts, abstract terms of knowledge are integral to the practice of power, to getting things done (1987: 17).

Smith highlights that "the replicable text makes it possible for the same words and images to be present to people in different places and at different times and hence introduce into people's doings the same organizing - though not determining - component" (2005: 206). In addition to analyzing the Guide and the Application, data from other texts pertaining to Professional Engineers of Ontario will be used such as annual reports, and information from their website. While the licensing process is represented in a straightforward fashion in the Application, it is only by cross-referencing these documents that a complete picture of the licensing process for immigrant engineers becomes visible.

This paper begins with a discussion of the regulation of engineering in Ontario and the engineering licensing process, followed by a textual analysis of the educational requirements sections of the Guide and the Application. The analysis of the Guide and the Application illustrates how immigrant engineers are constructed as exceptions to the licensing process in need of remedial work. In fact, the majority of applications processed by PEO are from immigrant men of colour with years of international work experience and higher levels of education than their Canadian educated counterparts (Bambrah, 2006b; PEO, 2006a). The Application presents a seemingly uncomplicated process when in fact the majority of applicants go through a highly subjective, individualized process. Through textual analysis, this paper will show how the Application renders invisible the actual process that immigrant engineers go through to meet academic requirements. The remainder of the paper contextualizes the practices of PEO within the broader engineering environment in Ontario, highlighting how the barriers of the licensing process directly shape the opportunities for immigrant engineers to find work and result in downward class mobility. 


\section{Engineering Barriers: An Empirical Investigation \\ into the Mechanics of Downward Mobility}

\section{Immigration and Labour Market Integration Issues}

Since 1995, federal immigration policies have prioritized the recruitment of skilled workers, and as a result there has been an influx of immigrant professionals belonging to regulated professions; from 1998 to 2000, engineers from China were the largest group of skilled worker immigrants (Couton, 2002). Because 65 per cent of immigrant engineers settle in Ontario, the policies and practices of PEO have a profound impact on the entire community of immigrant engineers in Canada. It is important to note that the majority of immigrants to Canada are from countries in South and South-East Asia; according to Statistics Canada from 2001 to 2006, 75 per cent of all immigrants were people of colour.

Despite the fact that immigrant engineers are assigned points during the immigration process for their education and work experience, researchers have shown that they face many barriers in gaining professional recognition from occupational regulatory bodies, employers and universities (Boyd and Schellengerg, 2007; Li, 2003; Mata, 1999; Skills for Change, 1998). Policies and practices of professional regulatory bodies in Canada have consistently been identified in the literature as barriers to immigrant professionals. The groundbreaking "Access: Task Force on Access to Professions and Trades in Ontario" (Cumming, Lee and Oreopoulos, 1989), the result of a task force struck in 1987 by the Ontario government to review the "rules and practices affecting entry to professions and trades to determine whether they have an actual or potential discriminatory effect on persons with training or experience from outside of Canada" (xi), identified professional credential assessment to be the most significant barrier. Other barriers relating to credential and experience assessment include lack of clear information about professional standards and registration requirements, devaluation of international academic qualifications and work experience, registration exams that do not demonstrate individuals' actual knowledge and skills, language tests that are too general and do not test occupation-specific terminology, lack of upgrading and bridge training opportunities, lack of internal appeals processes, and Canadian work experience requirements (Cumming, Lee and Oreopoulos, 1989; Li, 2003; Mata, 1999, Slade, 2003; 2008). As immigration policy has shifted to prioritize skilled workers, the problems associated with access to professions have intensified, particularly in Toronto where the majority of immigrants settle.

While the number of immigrant engineers who settle in Ontario, both male and female, is greater than the number of Canadian educated engineering graduates, immigrant engineers form a slim minority of those awarded licence. From 1978 to 2000, 85,780 engineers immigrated to Canada, over 12,000 of whom were women (Slade, 2003). Drawing from data from Citizenship and Immigration Canada, Professional Engineers Ontario and the Canadian Council of Professional Engineers I have estimated that between 1992 and 2000, there were 42,358 immigrant engineers who settled in Ontario and 29,031 engineering 
graduates from Canadian universities. In total, there were 71,389 engineers who could potentially apply to PEO for licence. During this time, PEO received 29,323 applications, representing 41 per cent of the total engineering pool. Of the applications, only 65 per cent $(19,202)$ were approved. On average 60 per cent of Canadian educated engineers apply for licensure (Boyd, 2001): extrapolating this percentage to the total, Canadian educated engineers would represent 17,418 (91\%) of the P.Engs awarded (Slade, 2003). While the current PEO numbers indicated that there are roughly equivalent numbers of licences awarded to Canadian-educated and immigrant engineers, immigrant engineers vastly outnumber Canadian graduates (PEO, 2007b). The situation for immigrant women is especially difficult as women only comprise seven per cent of the total PEO membership. This gender imbalance is reflected in the composition of the volunteer committees (discussed in the next section) so vital to the regulation of the profession (Women in Engineering Advisory Committee, n.d.). The numbers suggest that it is important for the engineering licensing process to be thoroughly reviewed with respect to equity based on gender and on place of education.

\section{The Regulation of Engineering}

Professional engineering is regulated more broadly and formally in Canada than in any other jurisdiction of the world (Professional Engineers Ontario, 2002: 4).

The regulation of professions falls within provincial authority. In Ontario, there are 38 self-regulated professions each with its own regulatory body and governing legislation. The professional regulatory bodies require that their members meet professional standards and ethics. They have the authority to set entry and training requirements, set standards of practice, assess qualifications and credentials, register qualified applicants and discipline members (Regulators for Access, n.d: "Ontario Regulators" section). Since 1937, engineering in Ontario has been a self-regulated profession administered by PEO for the provincial government specifically mandated under the Professional Engineers Act (1984) to establish, maintain and develop standards of (1) knowledge and skill; (2) professional ethics; (3) qualifications and standards of practice; and to promote public awareness of the role of PEO (PEO, 2005).

There are four elements to the licensing process of PEO: the basic criteria, the academic requirements, a Professional Practice Exam (PPE), and a work experience requirement. The basic criteria for admission to PEO demands that the candidate (a) be a Canadian citizen or permanent resident, (b) be proficient in English and (c) be of good character and reputation. Good character is judged through a series of 12 yes/no questions regarding previous licensure status, incidents of professional misconduct, drug or alcohol dependency and the presence of criminal record or charges in Canada or abroad. 


\section{Engineering Barriers: An Empirical Investigation \\ into the Mechanics of Downward Mobility}

The second element of the application process is an academic assessment. This criterion is satisfied if the applicant is a graduate of a recognized Canadian university program. If applicants have international credentials, the application is referred to the Academic Requirements Committee (ARC), a volunteer committee comprised of licensed engineers who assess the academic equivalency of the applicant. There are several different outcomes depending on place of education and length of engineering experience. The next step in licensure is sitting for the Professional Practice Examination which covers issues such as professional practice, ethics, engineering law and liability. After passing the PPE, the applicants have to fulfill a work experience requirement. Acceptable Canadian work experience is defined as, " ... at least 12 months of acceptable engineering experience in a Canadian jurisdiction, under a licensed professional engineer" (PEO, 2007a: 6). Experience is reviewed against criteria including application of engineering theory, exposure to project management, communication skills, practical experience and awareness of the social implications of engineering. For all applicants, there is a 48month work experience requirement with a minimum of 12 months worked in Canada. It is necessary for the applicant to have worked under the close supervision of a licensed engineer who can certify the quality of their work. Upon the successful completion of the academic requirements, PPE and work experience, engineers can legally use the title, "Professional Engineer" and append the letters, "P.Eng" to their name.

\section{The Guide, Application and Application Process}

The "Licensing Guide and Application for Licence" is a 12 page document divided into two components, the Guide and the Application. Sections in the Guide include "General Information" (one page), "PEO's Licensing/Admission Process" (three and three quarter pages), "Costs to Become Licensed" (one quarter of a page) as well as "PEO's Licensing/ Admission Process" flow chart (one page). The Application contains two sections, "How to Complete the Application Form" (two pages) and the "Application for Licence" (four pages). This official document is bound in a booklet and is printed on glossy paper with PEO's logo prominent on the title page.

This section of my analysis will focus on areas of the document that pertain to academic requirements, specifically, "Fulfilling the Academic Requirements" from the Guide as well as "Section 5: Academic Background" and associated instructions from the Application. The point of this analysis is to reveal the complexity of the process for immigrant engineers, as well as the subjective nature of the assessment. The Application for Licence Form is four pages long, divided into ten sections. The Academic Background information is approximately one quarter of a page long. Space is provided in this short section to fill in information pertaining to a maximum of three degrees (bachelor, post-graduate and additional). The required information is degree name, engineering discipline, university, 
city/country and date granted. The instructions for completing this section are seemingly straightforward:

Specify: type of earned undergraduate (bachelor's) and postgraduate (master's, doctorate) degrees (e.g. B.A.Sc., M.A.Sc., Ph.D.); the discipline of study; name and location (city/country) of the degree-granting institution(s); and the date (month/ year) each degree was granted (PEO, 2007a: 9).

While the Application presents the academic background section in a simple, uncomplicated fashion, the Guide provides a much more comprehensive description of the process that outlines a different set of criteria for internationally educated engineers. At the beginning of the "Academic Requirements" section, a distinction is made between engineering graduates from Canadian and international schools. For Canadian engineering university graduates, the only action they need to fulfill for the academic requirements is to have their official transcripts sent to PEO for review. The entire text in the Guide pertaining to the educational requirements of Canadian educated engineers reads as follows:

Applicants whose undergraduate engineering degrees have been awarded by a Canadian university whose program is accredited by the Canadian Engineering Accreditation Board (CEAB) are deemed to satisfy PEO's academic requirements but must ensure that original transcripts of their academic studies are sent directly to PEO by the institution from which they received their degrees. Photocopied transcripts and/or "student issued" transcripts are not acceptable (4).

For engineers not educated in Canada, however, the assessment of academic credentials is much more complex. The description of the process in the Guide is one and a half pages long. It states, "PEO will assess the academic qualifications of applicants who do not hold an undergraduate degree from a CEAB-accredited program to determine if they meet PEO's academic requirements for licensing" (4). The Academic Requirements Committee assesses all applications from non-Canadian educated engineers, reviews the academic transcripts and course descriptions, compares them to Canadian standards and assigns a series of examinations if it is judged that the applicant's credentials are not equivalent to Canadian standards (PEO, 2007a). Each application from a non-recognized university is assessed individually. Immigrant applicants are required to provide their original transcripts, a complete list of course descriptions as well as certified English translations of the documents for the committee to assess ${ }^{2}$. This assessment is reported to take two months to complete and is done solely on the basis of comparing the course descriptions and transcripts. These documents, therefore, are framed as factual representations of the candidates' knowledge and skill; the committee does not interview the applicant at this

2 The translations must be completed by either a member of the Association of Translators and Interpreters of Ontario or by a Professional Engineer who must certify that they are fluent in both languages. 


\section{Engineering Barriers: An Empirical Investigation \\ into the Mechanics of Downward Mobility}

stage of the process.

There are three outcomes of the initial academic qualifications review by the ARC: (1) equivalent to, (2) similar to, or (3) not equivalent to Canadian standards. If the qualifications are deemed equivalent to Canadian standards, the applicant advances to the experience requirement of the process. For the second and third outcome, there are three different loosely structured examination programs that the applicant may be assigned: the Confirmatory Examination Program, the Phase 1 Examination Program and the Specific Examination Program. These programs are referred to as the Technical Examination Program. The purpose of the examinations, according to the Guide is:

To ascertain whether an applicant's academic preparation is equivalent to that provided by an undergraduate engineering program accredited by the CEAB, or to remedy identified deficiencies in an applicant's academic preparation compared to a CEAB-accredited program (4, emphasis added).

The assumption in this text is that education from other countries is of lesser value.

If the qualifications are deemed to be "similar to that provided by a CEAB-accredited engineering program", then a Confirmatory Examination Program will be assigned. This program includes three technical exams and one complementary studies examination, the meaning of which is not made clear on the form. The goal of the Confirmatory Examination Program is to "give the applicant an opportunity to confirm that the content of his or her engineering studies is equivalent to the comparable CEAB-accredited engineering program" (4). If the applicant has a minimum of five years work experience they can make a request to have their file reviewed by the Experience Review Committee (ERC), another volunteer committee of professional engineers, to see if they can have the Confirmatory Examination Program waived. The ERC assessment may involve an interview with the applicant.

If the decision of the Academic Review Committee assessment is that the academic qualifications do not meet Canadian standards, the applicant is assigned a Phase 1 Examination Program or a Specific Examination Program depending on how the volunteer assessors judge the applicants' qualifications. If it is felt that the degree is equivalent to an honours science degree or a three year technology diploma, the Basic Examination Program is assigned. This program includes "at least four examinations in the Basic Studies category, additional discipline specific examinations, complementary studies examinations and the Engineering Report. Many of the terms used in this section of the form are not defined (for example, Phase 1, Basic studies, complementary studies) and therefore the details of the process are not clear. 
If the qualifications are judged to "fall between those of a technology diploma and those of an engineering degree", an individualized, Specific Examination Program is assigned. The Guide states, "this program may consist of up to 18 examinations and would include basic, technical and complementary examinations plus an engineering report" (5). If an applicant has at least 10 years of engineering work experience, they qualify to have their file reviewed by the ERC. The process is described as follows:

An interview is usually required. The ERC interview panel may recommend that the applicant not be required to write some or all of the assigned examinations with the exception of the examinations in the Basic Studies and Engineering Report, which the ERC interview panel cannot recommend waiving (5).

There is a strict time limit within which an applicant must successfully complete their assigned examinations and if it is not adhered to, an applicant's file will be closed; an applicant has to be vigilant with respect to the exam schedule as they are not regularly scheduled.

There are two conditions that may provide an applicant an exemption to assigned examination programs. The first condition is if the applicant has completed a graduate degree in Canada in the same engineering discipline as their non-Canadian undergraduate degree. The second condition is if the applicant has received a degree from an institution in a country covered under any of the Canadian Council of Professional Engineers (CCPE) Mutual Recognition Agreements, then the transcript will be reviewed and there is a possibility that their education will be considered equivalent to Canadian standards. The purpose of Mutual Recognition Agreements is to formally outline the conditions of equivalency between jurisdictions (countries) for academic programs or professional accreditation. PEO recognizes the "Washington Accord", initially an agreement between CCPE and the Accreditation Board for Engineering and Technology of the U.S.A. in 1980. This agreement was updated and expanded in 1989 under a new agreement, "Recognition of Equivalency of Engineering Education Courses/Programs Leading to the Accredited Engineering Degree," adding engineering accreditation organizations from Australia, New Zealand, Ireland and the United Kingdom. Since 1989, there have been two new signatories to the Washington Accord: Hong Kong in 1995 and South Africa in 1999. The Washington Accord states that all educational institutions accredited by the engineering associations in the various countries may be deemed equivalent to Canadian standards (CCPE, 2002). All other countries are considered "non-recognized", however, since CCPE has no official role in the provincial licensing process, PEO is not obliged to uphold the mutual recognition agreements negotiated by CCPE. According to the Council for Access to the Profession of Engineering (CAPE): 


\section{Engineering Barriers: An Empirical Investigation \\ into the Mechanics of Downward Mobility}

The engineering academic peer review process relies totally on the principle of equivalency on an individual by individual assessment and a limited database of accredited foreign engineering schools and universities, the development of which has not kept pace with the tremendous increase in diversity over the last thirty years. This is in spite of huge strides in information technologies. Since PEO does not recognize the Mutual Recognition Agreements signed by CCPE to facilitate foreign credential recognition this is a lengthy and cumbersome task (2007: "Positions Statement 1" section, 12).

Indeed, PEO does a great deal of administrative work in assessing applications from immigrant engineers. In 2005, for example, the Academic Requirements Committee assessed 2,272 applications from engineers not educated in Canada, completing on average almost 44 assessments per week. The Experience Requirement Committee had a slightly less demanding workload completing 1,348 assessments, approximately 26 per week (PEO, 2006a).

The "PEO's Licensing/Admission Process" flow chart in the Guide is a summary of the licensing process. The chart shows one box out of nine pertaining to the academic requirements section. It is titled "fulfill PEO's academic requirements". For Canadian educated engineers this process is a simple step; the licensing process as presented in the Application obscures the fact that engineers not educated in Canada have a lengthy and costly process to go through in order to satisfy the academic requirements. For a Canadian educated engineer, the licensing process will take four years to complete: this corresponds exactly to the work experience requirement. For an immigrant engineer, the licensure process may be much longer than four years due to a longer application process, exam schedules and difficulties obtaining work that would qualify as acceptable engineering experience. The application process can also be very costly for immigrant engineers. The initial application fee is $\$ 243.80$. If they are required to write technical exams, there is an administration fee of $\$ 370$ and $\$ 150$ charge for each examination. The Professional Practice Examination fee is $\$ 130$ and the final licensing fee is an additional $\$ 243.80$. Once an applicant is awarded a licence, they are required to pay annual dues of $\$ 212$. If an applicant is assigned a series of nine examinations, their total costs will be $\$ 2,634.40$. By comparison, for a Canadian educated engineer the total costs associated with licensure are $\$ 914.40$ (PEO, 2007a: 7) $)^{3}$.

3 As of November 2007: application fee (\$243.80), Engineer in Training registration (\$74.20 per year x $4=296.80$ ), Professional Practice Examination fee $(\$ 130)$, and Final Registration fee (\$243.80). There would also be related fees for exam preparatory courses. 


\section{The Varying Value of a Licence}

The "Licensing Guide and Application for Licence" is the point of entry to the engineering licensing process. There are two groups of engineers applying for this licence, graduates from Canadian universities and those who have been educated elsewhere and have immigrated to Canada: the licensing process and the significance of the licence vary greatly for these two groups. For a Canadian educated engineer, the professional licence is an extra designation in their career that confers a higher level of professional responsibility and a certain amount of status. An unlicensed Canadian educated graduate engineer can work without a licence as long as their work is supervised by a licensed engineer and they do not call themselves a "Professional Engineer"4; they are readily hired to work as engineers immediately after they graduate from university. In many workplaces, it is unnecessary for Canadian educated graduates to pursue licensure. In 2001, Boyd reported that only approximately 60 per cent of Canadian engineering graduates pursue a professional licence. The percentage of engineers who apply for licence has been a great concern to the professional regulatory bodies and they have devoted some energy to discover the underlying issues. The Canadian Council of Professional Engineers recruited focus groups of graduate engineers, employers, students and academics to explore the value of the professional licence for Canadian engineering graduates in 1999. They found that:

Employers do not require their employees to be licensed because they do not see value in it. Their prime concerns are education level and Canadian experience. Students see themselves as engineers when they get their iron ring [upon graduation from an undergraduate university program]. They felt that licensure was a higher but unnecessary step. Engineering graduates chose not to become licensed because their employers do not require it. Academics were philosophically in favour of obtaining the P.Eng., but felt that it is not a prerequisite for employment and therefore it is of limited value. (Professional Engineers Ontario, 2000: "Relevance of the Profession" section, 13).

The perceived lack of importance of the professional licence has led Professional Engineers Ontario to develop an awareness campaign, "Investing in the Licence", encouraging engineers to obtain a licence (PEO, 2006a).

While Canadian educated engineers can choose whether to pursue licensing, immigrant engineers are required to sign a declaration in the immigration process stating that they acknowledge that it is "their responsibility to obtain information on licensing requirements from the regulatory body that governs their profession" (Canadian Council of Professional Engineers, 2003: 9). For an immigrant engineer, then, pursing a professional designation is an obligation structured into immigration policy. Research has shown that for an

4 Only engineers who have a licence can call themselves "professional engineers" and use the designation P.Eng. 


\section{Engineering Barriers: An Empirical Investigation \\ into the Mechanics of Downward Mobility}

immigrant engineer to be considered for employment as an engineer, employers use the licence as a screening tool (Basran and Li, 1998; Canadian Council of Professional Engineers, 2003; Skills for Change 1995). Studies have identified that employers almost completely devalue international work experience (Reitz, 2001b) and that the equivalency of international credentials is not readily understood (Bambrah, 2006a; 2006b; Boyd and Schellenberg, 2007; Girard and Bauder, 2006; Li, 2003; Reitz, 2001a). This suggests that immigrant engineers are marginalized from the engineering labour force if they do not have a licence. The professional licence is the Canadian seal of approval that translates international credentials and experience into Canadian equivalency.

It has been argued that licensing bodies function as "labour market shelters," restricting entry into higher-status and better paying occupations and professions, reducing the competition for those already licensed (Boyd, 2000; Krahn et.al., 2000). Krahn et.al. have commented that "associations can be highly restrictive in their assessment of foreign qualifications not only to maintain high standards of practice but also to restrict competition for well-paying professional jobs" (2000: 78). In carrying out their legislated mandate of protecting the public good, regulatory bodies are also in a position to "define characteristics of occupational internal labor markets which create monopolies on products and/or services by controlling labor supply" (Boyd, 2000: 4). According to Girard's and Bauder's analysis of PEO's licensing process:

The formal and informal assessment processes of international credentials and foreign work experience [by PEO] are currently set up to tightly regulate which immigrants will be invited into the professional community and which ones are excluded. This careful selection facilitates social reproduction and maintains the existing cultural division of labour (2006: 51).

It is important to note that the members and leadership of PEO are also employers. The impact of the attitudes and work practices of this group significantly impacts the labour market integration of immigrant engineers.

\section{Concluding Thoughts}

The process used by Professional Engineers Ontario to evaluating international engineering qualifications is bureaucratic, subjective and time consuming. In spite of the large influx of immigrant engineers to Ontario since 1992, PEO has not developed policy to facilitate the recognition of international credentials and experience. They have, in fact, reinforced barriers by putting immigrant engineers with years of experience through a process designed for Canadian engineering graduates and, to a lesser extent, immigrants from former countries of the British Commonwealth where English is a dominant language. 
The vast majority of applicants to PEO, however, are university graduates from countries of the global south. The process, as it is written, normalizes and legitimates the education and career path of Canadian educated engineers. Immigrant engineers are constructed as exceptions to the process despite their numerical majority in applications and in the province. The form itself renders invisible the actual process through which immigrant engineers must go through to meet academic requirements. It is only by piecing the Application for Licence together with the Guide that the complex process for immigrant engineers becomes visible.

The difficulties encountered by immigrant engineers in obtaining a professional licence directly contribute to the poverty and downward mobility of these highly skilled professionals. According to the Daily Bread Food Bank in Toronto, 43 per cent of people who relied on the food bank in 2006 were immigrants with university degrees, nearly half of whom had been in Canada for four years or less (Daily Bread Food Bank, 2008). Newer immigrants, with higher levels of education, are experiencing more poverty than immigrants of the past two decades. In their research on chronic low income patterns of immigrants, Picot, Hou and Coulombe report that "one-half [of the chronically poor immigrants by the late 1990s] were in the skilled economic class, and $41 \%$ had degrees (up from $13 \%$ in the early 1990s)" (2007: 4).

Built into the application form and licensing process is an assumption that Canadian educational programs are superior to most international programs; PEO's policies direct the volunteer assessors of the Academic Review and Experience Review committees to identify perceived deficiencies in an applicant's education. The Ontario government supported the development of World Education Services (WES), an organization that specializes in academic credential evaluation to provide services to occupational regulatory bodies. A number of the 38 regulated professions use this service to determine academic equivalency; however, PEO will not accept assessments from WES. WES assesses over 50,000 applications annually from all countries of the world and maintains the "world's largest database of institutions, courses and degrees" (WES, n.d., "Trusted Credential Evaluations", 3). According to WES, "over 75 per cent of foreign credentials in the engineering, health care and IT fields we evaluated in the past year (2001) are equivalent to or exceed Canadian Standards" ("Canadian Taxpayers", 2002: 1). By sharp contrast, professional academic and work experience criteria evaluation at PEO is a timeconsuming, highly individualized process, conducted by volunteer professional engineers on an individual basis, and the outcome of the assessments are not compiled as a reference for future applications.

Much has changed since the 1989 "Access: Task Force on Access to Professions and Trades" report. There are now many different community-based bridging, mentoring, language 


\section{Engineering Barriers: An Empirical Investigation \\ into the Mechanics of Downward Mobility}

and employment preparation programs geared toward facilitating immigrant engineers' access to the labour market. Notably on the legislative front, Bill 124, the Fair Access to Regulated Professions Act, was passed in December 2006 and enacted on March 1, 2007. The purpose of this Act is, "to help ensure that regulated professions and individuals applying for registration by regulated professions are governed by registration practices that are transparent, objective, impartial and fair" (Government of Ontario, 2007a: 1). In March 2007, Jean Augustine was appointed as Ontario's first Fairness Commissioner, charged with the responsibility of working with all professional regulatory bodies to "ensure that the credentials of internationally trained professionals are evaluated fairly and transparently" (Government of Ontario, 2007b: 3). There has been a lively debate on the elements of the Bill (PEO, 2006b; PROMPT, 2006); however, it is too early to discuss how the passing of the Bill has impacted the engineering licensing process.

Institutional ethnography is not just a tool to expose ordinary work practices coordinated by texts that marginalize immigrant engineers from engineering work in Canada. The goal of detailing the engineering licensing process is overtly political, to provide a map whereby leverage points for social justice can be identified and pursued. The social ontology of institutional ethnography provides a lens to understand both the workings of the power and the tools to break down "systemic" discrimination into a series of work practices that can be challenged. In particular, this analysis raises questions about the individualized nature of the assessment process, and the capacity of the regulatory body's organizational structure and licensing process to fairly assess international educational credentials and experience. 


\section{Engineering Barriers: An Empirical Investigation \\ into the Mechanics of Downward Mobility}

\section{REFERENCES}

Bambrah, G. K. 2006a. Engineering Access Project: Final Survey Report. Retrieved August 17, 2008, from http://www.capeinfo.ca/docs/final_report_january_7_2006. pdf.

Bambrah, G.K. 2006b. What You Need To Understand About Engineering And Licensing. Retrieved August 18, 2008, from http://www.capeinfo.ca/docs/presentation_cape_ 2006.pdf

Basran, G.S. \& Z. Li. 1998. "Devaluation of Foreign Credentials as Perceived by Visible Minority Professionals”. Canadian Ethnic Studies, Vol. 30, No. 3, pp. 6-23.

Boyd, M. 2001. "Asian Engineers in Canada". In The International Migration of the Highly Skilled: Demand, Supply and Development Consequences. W. A. Cornelius and T. J. Espenshade (eds.). La Jolla: Center for Comparative Immigration Studies, University of California, pp. 85-109.

Boyd, M. \& G. Schellenberg. 2007. "Re-accreditation and the occupations of immigrant doctors and engineers." Canadian Social Trends, Vol. 84, pp. 1-10.

Boyd, M. 2000. Matching Workers to Work: The Case of Asian Immigrant Engineers in Canada. San Diego: The Centre for Comparative Immigration Studies.

“Canadian Taxpayers Lose Billions When International Job Talent Ignored." 2002, May 15. Canada NewsWire, p. 1.

Canadian Council of Professional Engineers (CCPE). 2003. From Consideration To Integration: An Environmental Scan Of The International Engineering Graduate Experience Before Immigration And Once In Canada. Ottawa: Author.

Canadian Council of Professional Engineers (CCPE). 2002. Guideline on Admission to the Practice of Engineering in Canada, Interpretive Guides. Retrieved August 10, 2008, from http://www.ccpe.ca/e/files/guideline_admission_intguide.pdf.

Council for Access to the Profession of Engineering (CAPE). 2007. Positions. Retrieved August 10, 2008, from http://www.capeinfo.ca/positions.php.

Couton, P. 2002. "Highly Skilled Immigrants: Recent Trends And Issues." Canadian Journal of Policy Research, Vol. 3, No. 2, pp. 114-123. 


\section{Engineering Barriers: An Empirical Investigation into the Mechanics of Downward Mobility}

Cumming, P., Lee, E. \& D. G. Oreopoulos. 1989. Access: Task Force on Access to Professions and Trades in Ontario. Toronto: Ontario Ministry of Citizenship.

Daily Bread Food Bank. 2008. Who's Hungry?. Retrieved July 24, 2008, from http:// www.dailybread.ca/get_informed/upload/WH-08-STATS2.pdf.

Girard, E. R. \& H. Bauder. 2006. "Assimilation and Exclusion of Foreign Trained Engineers in Canada: Inside a Professional Regulatory Organization.' Antipode, Vol. 39, No. 5, pp. 35-53.

Government of Ontario. 2007a. Fair Access to Regulated Professions Act, 2006. Retrieved August 18, 2008, from http://www.e-laws.gov.on.ca/html/statutes/english/elaws_ statutes_06f31_e.htm\#BK1.

Government of Ontario. 2007b, March 12. "McGuinty Government Nominates Jean Augustine As First-Ever Fairness Commissioner". Retrieved August 18, 2008, from http://www.citizenship.gov.on.ca/english/news/2007/n20070312.shtml

Hurst, L. 1999. “Tragedy of Immigrant Brain Drain.” February, 13. The Toronto Star, pp. 1-4.

Krahn,H., Derwing, T., Mulder,M., \& L. Wilkinson. 2000. "Educated and Underemployed: Refugee Integration into the Canadian Labour Market.” Journal of International Migration and Integration, Vol. 1, No. 1, pp. 59-84

Li, P. 2003. Destination Canada: Immigration Debates and Issues. Toronto: Oxford University Press.

Mata, F. 1999. The Non-Accreditation of Immigrant Professionals in Canada: Societal Dimensions of the Problem. Retrieved August 11, 2008, from http://www.pch.gc.ca/ progs/multi/societal/content_e.cfm.

Ng, R. 1996. The Politics of Community Services: Immigrant Women, Class and State (2nd Edition). Halifax: Fernwood Publishing.

Ng,R. 1995. “Multiculturalism as Ideological Practice: A Textual Analysis.” In Knowledge, Experience, and Ruling Relations: Studies in the Social Organization of Knowledge. M. L. Campbell and A. Manicom (eds.). Toronto: University of Toronto Press, pp. 3548. 


\section{Engineering Barriers: An Empirical Investigation \\ into the Mechanics of Downward Mobility}

Ng, R. 1993. "Racism, Sexism and Immigrant Women." In Changing Patterns: Women in Canada.SecondEdition. S. Burt, L. Code and L. Dorney (eds.). Toronto: McLelland and Stewart, pp. 279-301.

Ng, R. 1981. "Constituting Ethnic Phenomenon: An Account From The Perspective of Immigrant Women.” Canadian Ethnic Studies, Vol. 13, No. 1, pp. 97-107.

Picot, G., Hou, F. \& S. Coulombe. 2007. Chronic Low Income and Low-income Dynamics Among Recent Immigrants. Ottawa: Ministry of Industry.

Professional Engineers Ontario (PEO). 2007a. Licensing Guide and Application for Licence: How to Apply for a Professional Engineer Licence in Ontario. Toronto: Association of Professional Engineers of Ontario.

Professional Engineers Ontario (PEO). 2007b. Progressive Ideas for an Innovative Profession 2007 Annual Review. Toronto: Author.

Professional Engineer Ontario (PEO). 2006a. 2005 Annual Report: Investing in the Licence. Toronto: Author

Professional Engineers Ontario (PEO). 2006b. Presentation to the Standing Committee on Regulations and Private Bills in their deliberations on Bill 124, Fair Access to Regulated Professions Act, 2006. Retrieved August 12, 2008, from www.peo.on.ca.

Professional Engineers Ontario (PEO). 2005. 2005-2009 Strategic Plan: Investing in the Licence: PEO's Agenda for Change. Retrieved August 11, 2008, from www.peo. on.ca.

Professional Engineers Ontario (PEO). 2002. Report of the International Mobility Task Force. Retrieved August 13, 2008, from http://www.peo.on.ca/publications/Reports/ International_Mobility.html\#EXECUTIVE\%20SUMMARY

Professional Engineers Ontario. (2000). Strategic Plan 2000. Retrieved November 5, 2007, from www.peo.on.ca/registrar/StratPlan/stratplan_app5.htm.

Policy Roundtable Mobilizing Professions and Trades (PROMPT). 2006. Written Submission to the Standing Committee on Bill 124, Fair Access to Regulated Professions Act, 2006. Retrieved August 18, 2008, from http://www.promptinfo.ca/ Library/Docs/Bill\%20124.pdf 


\section{Engineering Barriers: An Empirical Investigation into the Mechanics of Downward Mobility}

Regulators for Access. n.d. Ontario Regulated Professions. Retrieved August 18, 2008, from http://www.regulators4access.ca/html/introreg.htm.

Reitz, J. 2001a. "Immigrant Success in the Knowledge Economy: Institutional Change and the Immigrant Experience in Canada, 1970-1995." Journal of Social Issues, Vol. 57, No. 3, pp. 579-613.

Reitz, J. 2001b. "Immigrant Skill Utilization in the Canadian Labour Market: Implications of Human Capital Research." Journal of International Migration and Integration, Vol. 2, No. 3, pp. 347-378.

Skills for Change. 1998. Dignity and Opportunity: Accessing the Economic Contribution of Foreign-Trained Newcomers. Retrieved August 15, 2008, from http://www. skillsforchange.org/library/downloads/dignity_and_opportunity.pdf

Skills for Change. 1995. Building Bridges: Identifying Opportunities and Overcoming Barriers to Employment and Licensure for Foreign-trained Engineers in Ontario. Toronto: Skills for Change.

Slade, B. 2008. From High Skill to High School: The Social Organization of Volunteer of "Canadian Work Experience" for Immigrant Professionals. Unpublished Doctoral Dissertation, University of Toronto, Canada.

Slade, B. 2003. A Critical Feminst Analysis of the Marginalization of Immigrant Women Engineers: Subtle Semantics, Redundant Assessments and Conflicting Jurisdictions. Unpublished Master's Thesis, University of Toronto, Canada.

Smith, D. 2005. Institutional Ethnography: A Sociology for People. Toronto: Altamira Press.

Smith, D. 1997. "Report and repression: Textual Hazards for Feminists in the Academy." In Dangerous Territories: Struggles for Difference and Equality in Education. L.G. Roman and L.Eyre (eds.). New York: Routledge, pp. 161-178.

Smith, D. 1987. The Everyday World as Problematic: A Feminist Sociology. Toronto: Univerisity of Toronto Press.

Statistics Canada. 2008. Canada's Ethnocultural Mosaic, 2006 Census. Ottawa: Ministry of Industry. 
Women in Engineering Advisory Committee. n.d. Retrieved August 19, 2008, from http:// www.ospe.on.ca/weac.html.

World Education Services (WES). n.d. Retrieved August 18, 2008, from http://www.wes. org/ca/about.asp.

Zheng, I. 2005. Conference Address. Retrieved April 12, 2005 from http://www.cthrb. ca/English/Documents/CTHRBMiniSymposiumIvyZhengRemarks.doc 